\title{
Simulated National Identity and Ascendant Hyperreality in Julian Barnes's England, England
}

\author{
Hassan Abootalebi, $\mathrm{H}{ }^{1} *$ \& Niazi, $\mathrm{N}^{2}$ \\ ${ }^{1,2}$ Lorestan University, IRAN \\ *Corresponding author; Emails: abootalebi2010@gmail.com; nozar_2002@yahoo.co.in
}

\begin{abstract}
The paper sets out to analyze Julian Barnes's novel England, England (1998) in the light of Jean Baudrillard's concepts of simulation and hyperreality. According to Baudrillard, what we experience in today's world is a simulation of reality superseded by signs and images, and therefore we are living in a hyperreal world. Barnes's book offers a representative sample of hyperreal world in which Martha, the protagonist, finds herself troubled. Although initially she is impressed by the glamour of the theme park named England, England later on she loses interest in it when she comes to realization that everything about it is fake. This condition, making her think of her own identity and true self, finally leads her to leave the theme park and settle in the village of Anglia where she hopes to discover her true nature and regain her lost happiness.
\end{abstract}

Keywords: Barnes; England; Baudrillard; simulation; hyperreality.

\section{INTRODUCTION}

Known as one of the prominent figures in the realm of postmodernism, Jean Baudrillard has over the past few years exerted enormous influence over various fields. His critiques of contemporary societies are well known, but his most seminal book which includes his most polemical theories is simulacra and simulation (1995) in which he claims that reality is no longer what we used to think of. It, he asserts, has been supplanted by images most of which devoid of reality. What individuals experience in today's societies is more often than not merely a simulation of reality. $\mathrm{He}$ maintains that in the postmodern age the distinction between real and its representation has been blurred, we no longer are able to differentiate between a real and a copy; we are bombarded by images and signs. Consequently it is utterly impossible to distinguish which is real, and which is not. To begin with, a concise elaboration of the abstract-mentioned notions would be helpful. Simulation, broadly defined, is the act of producing something and pretending it to be real when it is not. It is the generation by models of a real without origin or reality: a hyperreal. Baudrillard (1995) identifies three categories of simulation: the first is a patent copy of reality which is distinguishable by consummate ease. The second is so good and consummate that it would be almost impossible to differentiate between the real and its copy. The third category of simulation but has no affinity to any reality, generating a reality of its own which is at odds with the real world. Baudrillard discusses how simulation deals with reality, and proposes that in the process of reproducing reality it makes use of four models or stages:

1. Reflecting a profound reality.

2. Masking and denaturing a profound reality.

3. Masking the absence of a profound reality.

4. Having no relation to any reality whatsoever. (p. 6)

Richard J. Lane (2000) commenting on the four stages of reality reproduction makes this clear:

With first - and second-order simulation, the real still exists, and we measure the success of simulation against the real. Baudrillard's worry with third and fourth-order simulation is that the model generates what he calls hyperreality-that is, a world without a real origin. So with third and fourth order simulation we no longer even have the real as part of the equation. Eventually, Baudrillard thinks that hyperreality will be the dominant way of experiencing and understanding the world. (pp. 86-7)

Baudrillard considers Disneyland, a very large theme park near Los Angeles, as belonging to the third-order simulation:

Disneyland is presented as imaginary in order to make us believe that the rest is real, whereas all of Los Angeles and the America that surrounds 
it are no longer real, but belong to the hyperreal order and to the order of simulacrum. It is no longer a question of a false representation of reality (ideology) but of concealing the fact that the real is no longer real, and thus of saving the reality principle. (10)

Baudrillard argues that Watergate (the political scandal in the US in 1970s which caused President Nixon to quit his job) like Disneyland is another scenario belonging to the third-order simulation. It was "a simulation of scandal for regenerative ends" ( $p$. 12).The Gulf War too, according to Baudrillard, was only a simulation. In the introduction to the Gulf War Did not Take Place (1991), a CNN reporter narrates a moment in which he asks other reporters involved in the war what was occurring and interestingly found that they themselves watched CNN to see what was happening. "News is generated by news, or the source of the news is also the news... News is producing the reality of the war, not only for viewers, but for those involved" (Lane, 2000, p. 106).

In England, England Barnes concerns himself with the creation on the Isle of Wight, of a colossal theme park by the entrepreneur Sir Jack Pitman that assembles everything that comes to the mind when one hears the words England and Englishness. The novel consists of three main parts: the first part focuses on the protagonist Martha Cochrane and her memories of childhood. The second part focuses on England, England, the theme park and the way hyperreality comes into being. The last part called Anglia, refers to the name of the village where Martha decides to spend the rest of her life after leaving the theme park.

\section{DISCUSSION}

The discussion of the novel within the concerned theoretical framework can be divided into three parts, which are interrelated thematically. The first part deals with the protagonist's childhood memories, the second part concerns itself with the construction of a colossal theme park (simulation of a hyperreal world) and the rationale behind it, and the last part portrays the protagonist leaving the theme park and taking refuge in a village.

\section{Tampering With Reality}

From the outset of the novel Martha Cochrane, the protagonist, questions the way memory operates, and expresses her mistrust of it. Trying to remember what her first memory was, Martha fails to do so:

Your first memory wasn't something like your first bra, or your first friend, or your first kiss, or your first fuck, or your first marriage, or your first child, or the death of your first parent, or your first sudden sense of lancing hopelessness of the human condition-it wasn't like any of that. It wasn't a solid, seizable thing... A memory was by definition not a thing, it was.... memory. A memory now of a memory a bit earlier of a memory before that of a memory way back when...it was likes a country remembering his history: the past was never just the past, it was what made the present able to live with itself. The same went within individuals, though the process obviously wasn't straightforward. (pp. 7-9)

The analogy made between the unreliability of an individual's memory and a country's past history is very meaningful and suggests that one could always fabricate stories around them to make them sound more attractive and plausible. Martha's first memory, "an innocently arranged lie" (p. 8) was assembling her counties of English jigsaw puzzle, sometimes with a piece missing. This was not a false memory, but still not unprocessed since she could not recall the details. Once the missing parts are found and the puzzle completes, she would feel happy. "Staffordshire has been found, and her jigsaw, her England, and her heart had been whole again" (p. 9). The word "whole" here takes on an ironic interpretation because when her father abandoned the house ostensibly to find the missing part of the puzzle; Nottinghamshire, and he never returned, neither the jigsaw nor her heart was made whole again, "this all seemed-what?-not untruthful, but irrelevant, not a way of filling the exact, unique, fretsaw-cut hole within her. She asked for Nottinghamshire" (p. 26). This image, as Guignery maintains, "provides a metaphor for the essence of history and memory, whose wholeness is a mere illusion" (The Fiction of Julian Barnes, 2006, p. 106). Thus, the first part of the novel lays the conceptual setting for the creation of the theme park and theoretically justifies the rationale behind such a project.

In the second part of the novel, the reader is introduced to Sir Jack as entrepreneur, innovator, ideas man, arts patron and family man. These words were chiseled on a slate hanging in his quote room in Pitman House. His new enterprising project, which Sir Jack calls a "mighty Project," is building a colossal theme park, simulating Old England. He asks Jeffrey, his Concept Developer to carry out a survey on top characteristics and quintessence of England and Englishness around the world. He also demands Dr. Max, his Official Historian to probe how much domestic people know of their own history, since 
"what domestic doesn't know the rest of the world won't be shagged to find out'(p. 58). Pitman seeks to exploit people's rudimentary knowledge of their country's past so as to distort it in a way it would have an appeal for the visitors around the world. He is not concerned about the verisimilitude of information conveyed to individuals, just to be palatable to them. What visitors to this constructed world will come across would be indeed a distorted history. Therefore, reality and simulation here will be so adeptly blurred that no visitor would be able to differentiate between the two. Reality and simulation of reality will be mingled in a way that visitors would savor what they will be provided with, without questioning their authenticity and veracity. Replica will offer more pleasure than original is supposed to do.

Sir Jack intends to turn the Isle of Wight, the little cutie, the little beauty, pure diamond, little jewel, "a location dying for makeover and upgrade" (p. 75) where the main industry used to be smuggling, into a great theme park (one should take note of the irony here). He aspires to create this as a microcosm of Old England; an exact replica of the original country. The replica will simulate the features associated with it in a manner that would gradually create a world of its own; a copy without an origin. It would include Old England's major tourist attractions, so that people would no longer be willing to visit the real country. Baudrillard contends that hyperreality comes to being when a copy precedes its original, when the copy no longer bears any relation to its original, constructing an independent world divorced from reality. The intended project corresponds with this contention in that it supersedes Old England, it creates a world of its own, and it is divorced from the outside world. England, England is thus a copy preceding its original in roughly all respects.

A hyperreal world is made possible through tampering with the real. An interview conducted by Dr. Max with a 49-year-old man, being the representative of the target group, indicated how people's understanding of their past history was rudimentary. The kind of response given to a question about the Battle of Hastings and its aftermath made Dr. Max terribly disappointed to discover how little people knew of their past history:

There had been many others like this, and they were beginning to depress him. Most people remembered history in the same conceited yet evanescent fashion as they recalled their own childhood. It seemed to Dr. Max positively unpatriotic to know so little about the origins and forging of your nation. And yet therein lay the immediate paradox; that patriotism's most eager bedfellow was ignorance, not knowledge. (p. $80)$.
This condition provided Pitman and his staff with an opportunity to treat history as they pleased, fusing it with fantasy so it would be perfectly acceptable. Thus, the natives' inadequate knowledge of their own history became the stepping stone on which the mighty project, the simulation of national identity, was founded, and thus the forging of a false identity was commenced. Individuals then would face a history combined with fantasy, and therefore more pleasing to be welcomed. The borderline between what actually occurred and what was added would be hardly perceptible.

Having reviewed the list containing the quintessence associated with England, Sir Jack expunged from it such vices as homosexuality, hypocrisy, and whinging as "faulty polling technique" (p. 82) and weighed the rest. He removed them as unnecessary parts of the survey, and instead devoted his attention to the positive characteristics associated with Englishness, especially to historical monuments and places of interest. The negative features were thus deliberately left out.

In the constructed universe of Pitman, Even the qualities related to historical figures are intentionally massaged in order to suit contemporary interests. Concerning Nell Gwyn (the English actress who became the lover of king Charles II), for instance, they changed the story in a way to make her more palatable to the taste of people: "a little massaging, to bring her into line with third millennium family values" (p. 89), making her look older, and losing her social and religious background to fit marrying the king. In this constructed world no historical event is immune to change. No restrictions are placed on Pitman and his associates so that they are free to satisfy their cravings for tampering with reality. A concocted history takes the place of Old England's real history in such a way that it causes English subjects to have no recollection of their true past, to take the invented history for granted, and consequently to create a fallacious national identity. How can then one in such a situation orchestrated by entrepreneurs, seek the truth?

\section{The Glamour of Hyperreality Over the Real}

The theme park being the brainchild of Sir Jack is constructed with the purpose of, as he himself puts it, "making visitors feel that they have passed through a mirror, that they have left their own worlds and entered a new one, different yet strangely familiar, where things are not done as in other parts of the inhabited planet, but as if in a rare dream" (p. 112). This world is designed based on the quintessence 
gathered through a survey. "Among the quintessence, past glories overshadow such present-day banalities as whinging, it is England in aspic, disabled by its past, backward-rather than forward-looking, assembling a populist past for consumer entertainment" (Groes \& Childs, 2006, p. 85). Sir Jack subsumes everything associated with England: stretching from White cliffs of Dover to legendary and literary figures such as Robin Hood, and Dr. Johnson. Even the king and the queen are convinced to relocate to the theme park and make a speech. Sir Jack's negotiating team endeavors to convince the Royal Family by saying, "it is country's top cash crop. There would be a modernized Buckingham Palace, paying no taxes, and no intrusion by journalists since the only newspaper would be The Times of London" (p. 136). The main idea behind this relocation, however, according to Sir Jack's team was to "restore the glamour and pizzazz which had been so insolently wrenched from the Royal Family in past decades" ( $p$. 136). After great flattery and financial promises, the King and the Queen concurred to fly to the Island for the opening ceremony. Thus, the irony of situation here reaches its peak when the royal family show inclination to become part of the mighty project; the simulated world. In this way, the whole culture was gradually assembled into hyperreality.

Now tourists instead of having to travel around London to visit different historical and monumental places are here given the opportunity to take pleasure by visiting them all in England, England. It has a world of its own, "an offshore replica of an England that does not exist, or that exists only in the minds of international focus groups whom sir Jack asks to list the characteristics, virtues or quintessence suggested to them by the word England" (Greaney, 2006, p. 146). While the theme park is populated by numerous tourists from around the world, Old England is by contrast fading into oblivion. We are thus not dealing with the original and real, but a simulated England. The French philosopher who is invited to England, England is the one who endorses the project by believing that:

We are talking of something profoundly modern. It is well established- and indeed it has been incontrovertibly proven by many of those I have earlier cited- that nowadays we prefer the replica to the original- we prefer the reproduction of the work of art to the work of art itself, the perfect sound and solitude of the compact disc to the symphony concert in the company of a thousand victims of throat complaints, the book on tape to the book on the lap...It is important to understand that in the modern world we prefer the replica to the original because it gives us the greater frisson. (p. 53)

The facts about Old England are disappointing as we are told "its diminishing population knew only inefficiency, poverty, and sin; depression and envy were apparently their primary emotions" (p. 189).Therefore in the constructed world everything is intended to look wholly glamorous and satisfactory. Attempts are made to create a strong sense of patriotism, "not one based on tales of conquest and sentimental recitations, but one which, as Sir Jack might have put it, was here, was now, and was magic" (p. 189). Those behind this simulated universe become so excited because this "repositioned patriotism would provoke a proud new insularity" ( $p$. 189). They were proud to have been able to create a new England that could get the better of the Old one. Consequently tourists around the world, after visiting the constructed world, would show no inclination to see the real, the old one.

Even Dr Max, the official historian reinforces the precedence of replica over original, contending that what people always look for is the replica not the original. Martha explains how the famous statue of David by Michelangelo was removed and supplanted by a copy, which proved just as popular with visitors as the original. Surprisingly, a survey showed that ninety percent of those who were asked evinced no interest to visit the original statue. The survey conducted by Pitman House concluded that tourists until now had visited the original places because there was no alternative to these sites, and if tourists were given a choice to choose from an "inconvenient original," or a "convenient replica," most of them would be interested to visit the latter. "Don't you think, as Martha says, "it is empowering and democratic to offer people a wider choice, whether in breakfast food or historic sites? We're merely following the logic of the market" (p. 170). The idea of distorting historical facts for commercial purposes is clearly stated by Martha in the last utterance. Her utterances illustrate the impact of a replica, and how much it can overshadow an original. The constructed world is thus "a kind of parable about the fate of a national identity as Barnes's characters wrestle with doubts about the reliability of memory, the uses of the past, and the possibility of authentic contact with others in a world of simulation and hyperreality" (Bently, 2005, p. 95).

They learnt how to massage history, how to construct a false national identity, and how to make the project enjoy a lot of success; nonetheless, it bore no relation to the real world. According to Nick Rennison (2005): 
"eventually the fake England with its ersatz versions of Stonehenge and Big Ben, its extras dressed as cheery local bobbies and Robin Hood and his Merry Men, and with its own royal family, overtakes the real England which reverts to an almost pre-industrial state" (p. 26).

One major part of their task was "the repositioning of myths for modern times" (p. 139), a distortion of history in a manner that best suits the purpose of those behind the project. The history of Robin Hood and His Merrie Men, for instance, is altered by establishing a female presence (Maid Marian) from the start, in a way to appeal to the taste of the present by questioning if and why the Men were all men, and by suggesting that even the name of Robin is sexually ambiguous. The word Hood, meaning a piece of clothing that is ambisexual, is in question as well. Dr. Max is thus instructed to delve into the issue and his findings suggest the presence of Marian within the Band as later reported, leading to three possibilities, as Martha deduced from Dr. Max's report: first, Marian was conforming to "chivalric code of the times" ( $p$. 143) Second, it was a "martial play" to escape sex. Third, Marian should have been "biologically male."

\section{Theme Park Providing a False National Identity}

After the Royal Family flew to the Island, it gained its independence. Sir Jack was appointed as Island Governor, and the Island threw off the yoke of Westminster and became an enormously popular tourist destination attracting many people from around the world. A vacation here may seem expensive, yet it is "a once-in-a-lifetime experience" (p. 169). Moreover, after visiting England, England there would be no need for visitors to see the old one. When asked by the journalist about her impression of the Island, Maisie Brankfordfrom Franklin expressed her complete satisfaction with the project, "we heard that England was kind of dowdy and old-fashioned, and not really up with the cutting edge of the modern world. But we've been mighty surprised. It's a real home away from home" (p. 170). In this way a false national identity begins to evolve.

Whereas the facts about Old England were disappointing as being in a state of "free fall, an economic and moral waste-pit" (p. 189) where penury was most prevalent and the manifold pathetic realities needed attending to, conditions in the Island were absolutely the opposite, "a modern patriotism" began to flourish. A totally disparate replica compared to its original developed: "Here on the island, they had learnt how to deal with history, how to sling it carelessly on your back and stride out across the downland with the breeze in your face. Travel light: it was true for nations as well as for hikers" (p. 190). However, to forge a new national identity through creation of a hyperreal world, here the theme park is not without its problems.

\section{The Theme Park Being Problematized}

Though the simulated universe enjoys a lot of success, it comes across some problems. There are complaints against the person who impersonates Dr. Johnson as he fails to present Dr. Johnson the way the theme park authorities expected him to do, believing that "he's depressing the company bydining with the visitors" (p. 194) and showing traits of "moodiness, melancholy, and a lack of civility towards those sharing his table"(p. 194). Martha reminds him of being engaged to play Dr. Johnson, "we want you to be Dr. Johnson, don't you understand? (p. 197). Since the impersonator is dissatisfied with his personal life as it has been "a waste barren of time, with some disorders of body, and disturbances of the mind very close to madness" (p. 198), he has taken refuge in playing Dr. Johnson's role. The present hyperreal of playing Dr. Johnson provides him with an opportunity to at least for a brief spell take his mind off the painful realities of his life. He opts for hyperreality so as not to recollect his real life being replete with bitter experiences and painful memories.

Another trouble facing the project rises from Robin Hood and his band that are central to the island. The band "a primal myth, repositioned after considerable debate" (p. 207), starts to cause trouble. Mr. Hood claims that the presence of homosexuals among them is "detrimental to good military discipline" (p. 210), and complains of not having had sex for months. These problems along with many others obsess Martha as she cannot come up with a viable solution: "what if they all took into their heads to behave like that? What if the King decided he really wanted to reign...what if robins decided they didn't like the snow?" (p. 211).

\section{The Problem of Personal Identity}

Martha Cochrane, despite being part of the Theme Park is the only one among individuals involved in the project who seeks true identity. All other are quite content with their enterprising project. She has been striving for finding a way to know her true nature and identity, but seems to have arrived at no definite conclusion. While at home with Paul, Martha talks to herself:

And the surrounding problem was, how did you know what your nature was?; that most people located their nature in childhood...here 
was a photo of herself when young, frowning against the sun sticking out her lower lip: was this her nature or only her mother's poor photography?; but what if this nature was no more natural than the nature Sir Jack had satirically delineated after a walk in the country?; because if you were unable to locate your nature, your chance of happiness was surely diminished;... (p. 212).

Martha's mind, as the above quotation suggests, is very much engaged with the concepts of reality, true nature, and personal identity as elemental ingredient for happiness. She discusses her concern with Dr. Max, expressing her disapproval of the project, but Dr. Max like others espouses the rationale behind the project, and Martha finds it hard to go along with him. At home, again Martha ponders over her own life, the cause of her unhappy feelings, and the growing distance between herself and Paul. Dr. Johnson perhaps was right, "they had lost that tenderness of look and that benevolence of mind" (p. 206). Martha finds herself entangled in a predicament. She feels falling in love with Johnson. Paul somehow becomes suspicious of her behavior, trying to find out whether she is having an affair with someone. Martha refutes the claim, and is uncertain whether to discuss the problem with Paul or not. But that she has fallen in love with someone who does not exist anymore, died centuries ago, sounds utterly absurd. The fact that Martha has fallen in love with Dr. Johnson implies that she is filled with a sense of nostalgia for the past that comes in sharp contrast with present. She has gradually lost her trust in the hyperreal world of the Theme Park, representing a new England, losing her contact with it, and therefore no longer happy with the status quo. Despite Dr. Max's historical skepticism, Martha believes in happiness and strives to explore a world in which it would be attainable.

When she said she believed in it, she meant that she thought such a state existed and was worth trying to attain;

- true to your nature;

- that is true to your heart;

- but the main problem, life's central predicament, was, how did you know your heart? (p. 211).

Barnes, to quote Miracky, depicts a world where hyperreality triumphs on the one hand, and "incurporates elements that reach for an authentic human experience of the real" on the other. This situation causes the novel to remain in a position somewhere "between homage and parody of the dominance of the hyperreal." The relation between Martha and Paul can be thought of as a "possible antidote to the hyperreal world of the project as it is described using the language of the real" (qtd. in The Fiction of Julian Barnes, 2006, p. 112). It is evident in the conversation between the two when Paul says: "I just think you're...real. And you make me feel real. Is that good enough for you?" (p. 127).

Martha seems to have lost all hopes in finding happiness in a world where everything seems unnatural, and perhaps it is only in the world of her own heart that she hopes to discover her true nature and get a sense of identity. After a few years of wandering she finally decided to detach herself from the world of the Theme Park and went back to Anglia, a village where she belonged.

\section{The Success of Theme Park and Defeat of Old England}

By the time Martha left, Jack was ruling the island and he had managed to successfully deal with the subversive tendencies of such employees as the new Robin Hood and his Merrie men by being brought back to outlawry. Dr. Johnson had been moved to Dieppe hospital and "deep sedation was prescribed to control his self-mutilating tendencies" (p. 230). After a couple of years working as CEO, Paul was removed. Sir jack's "ninth symphony" brought him wealth and market applause. He was acknowledged as both innovator and man of ideas. By that time Old England had utterly lost its contact with the world. "A time of vertiginous decline" (p. 234) was ascendant in the original country. The tourist industry declined sharply, the currency was ruined by speculators, and the relocation of the Royal Family brought about the expatriation to become the vogue among the people of high social class; while "the country's best housing stock was bought as second homes by continental Europeans"(p. 234). Old England was consigned to oblivion. The constructed England, England engendered a memory not founded upon truth, but on falsity, a memory that began to flourish so that the world no longer recalled Old England. It was completely overshadowed by England, England:

The world began to forget that England had ever meant anything except England, England, a false memory which the island worked to reinforce; while those who remained in Anglia began to forget the world beyond. Poverty ensued, of course, though the world meant less in the absence of comparisons. If poverty did not entail malnutrition or ill health, then it was not so much poverty as voluntary austerity. Those in search of traditional vanities were still free to migrate. Anglians also discarded much of the communications technology that had once 
seemed indispensible...Coal was dug again, and the kingdoms asserted their differences; new dialects emerged, based on the new separations. (p. 236)

The existing hyperreal society, indeed, preceded the real one, making people divert their attention away from Anglia which is in dire need of help and attention. It engendered a bogus memory and identity whose continuing dominance led to seemingly ineluctable implications.

\section{Anglia as an Alternative to the Hyperreal World of Theme Park}

The village where Martha had now lived for five years was "neither idyllic nor dystopic" (p. 239). There she made friends, read books, and grew turnips and cabbage in her garden. After residing in Anglia, Martha abandoned her attempts wrestling with the concepts of identity and reality; she entertained herself with the village fete and activities, trying to follow a simple life. She was not completely content with her current situation, but it appeared that she had no alternative. She had returned to Anglia as a "migrant bird" rather than a "zealot" and although she was conscious of the lack of originality, she was incapable of effecting a change and had no intention of concerning herself with such matters. She was not certain about anything, and therefore engaged herself with village activities:

These questions were not debated in the village: a sign perhaps that the country's fretful, psoriatic self-consciousness had finally come to an end... She herself no longer itched with her own private questions. She no longer debated whether or not life was a triviality, and what the consequences might be if it were. Nor did she know whether the stillness she had attained was proof of maturity or weariness. (p. 241)

It is probably true, as Nick Bently (2005) maintains: "Anglia can be read as prescription for the anxiety over what is 'real' that runs throughout the novel. The unreliability of memory, the dishonoring and disowning of an imperial past, the sense of personal betrayal linked to national letdown-all complicate and thwart the possibility of authentic identity" (pp. 103-4). Or as Greaney suggests, the last part of the novel can be called a "failed demuseumification", in which Martha leaves the museum of Englishness with only finding out one thing-that is, England has become a museum (p. 149). To put it simply, she is not capable of doing anything special. Martha quits England, England while being aware of its lack of originality, but unable to effect a change. What Barnes has thus implicitly emphasized is that "Englishness is an empty illusion" (Groes \& Childs, 2006, p. 93), or as Barnes himself maintains: "the novel is about the idea of England, authenticity, the search for truth, the invention of tradition, and the way in which we forget our own history" (Barnes, 2006, as cited in Guignery, 2006, p. 105).

Thus, the village of Anglia can be taken as a metaphor for Martha's heart where she hoped to find some traces of intact reality, genuine identity, peace and happiness. She came to acknowledge that she was fading, "transformed into an old maid" (p. 242) and thus endeavored to involve herself in matters of little importance, spending her time on trivialities in the hope that she would forget the present hyperreality to which she could not attend and was beyond her control. Since she had no power to change the hyperreal world of the Theme Park, simulated England, she tried at least not to be a part of it anymore, like the villagers who were unaware of the tribulations facing Old England. She no longer thought of the issues which concerned her greatly while working in the theme park. In the village she discovered the simple and solid reality of the soil out of which she grew turnip, cabbage and other vegetables. The material reality of the soil was a world apart from the simulated world of the theme park. Here nature emerged forcefully from the heart of the soil claiming its originality. That was perhaps the only solid reality she could rely on.

\section{CONCLUSION}

As argued, England, England concerns the construction of a simulated world on the Isle of Wight. The constructed 'utopian' world is intended to divert people's attention from the 'dystopian' one, Old England. Anything represented in this new world is a simulation of Old England that is intended to look more glamorous and satisfactory, in a way that almost all visitors after visiting the theme park would not like to see the real England. Since more often than not, reality does not give individuals pleasure, its simulation is a potentially acceptable alternative offering them the kind of satisfaction they always seek. However, it is due to visitors' limited and rudimentary knowledge, as Dr.Max's survey suggested, about the history of England and its culture that makes them believe in whatever presented in the simulated world of England, England as real. Thus, Barnes in his novel tries to demonstrate how a whole culture could be assembled into a world of hyperreal, and how a false national identity might evolve. 
Martha, the protagonist of the novel and as a part of the project, initially became overwhelmingly impressed by the glamour of the simulated world, but gradually lost interest in the entire project as she came to the realization that everything presented in the theme park was fake and lacked originality. She found herself in a simulated world in which nothing seemed genuine. This condition depressed her and made her question her own identity as well as true nature. She knew that only by discovering her own true nature she could regain her lost happiness. Barnes's fiction has a powerful resonance in contemporary life. In modern societies, according to Baudrillard's consumerist theory, individuals' lives are enormously influenced by constructions made of signs and images, which refer to no reality or bearing little resemblance to the one we inhabit, a hyperreal world. In order to save herself, Martha leaves the hyperreal world of England, England and seeks refuge in the village of Anglia. To place Anglia in sharp contrast to England, England is deliberate and very meaningful on the part of the author. His aim is to compare and contrast the simplicity and naturalness of the world presented by the village with the glamour, artificiality, and fakeness, of the theme park, simulated England.

As the study shows, there are close affinities between Baudrillard's concepts of hyperreality and simulation and contemporary life presented by England, England. Having made use of such notions, Barnes very beautifully portrays how awful and sometimes irreversible the damages caused by hyperreality might be, how individuals embroiled in it can grow apathetic about the world and its problems, and how traumatic, after abandoning the unreal universe, this experience could be for them. Disillusionment and depression, as experienced by Martha, are thus expected concomitants of it. The whole story implies how and in which ways a hyperreal world supersedes a real one and suggests the disastrous effects awaiting modern societies if they walk away from real life and resort to the hyperreal.

\section{REFERENCES}

Groes, S. \& Childs, P. (Eds). (2011). Julian Barnes: Contemporary critical perspectives. London: Continuum.

Barnes, J. (1998). England, England. New York: Vintage.

Baudrillard, J. (1995). Simulacrum and simulation. Trans. Sheila Faria Galser.

Bently, N. (Ed.). (2005). British fiction of the 1990s. London: Routledge.

Childs, P. (2006). Contemporary novelists: British fiction since 1970. London: Palgrave Macmillan.

Greaney, M. (2006). Contemporary fiction and the uses of theory: The Novel from Structuralism to Postmodernism. New York: Palgrave Macmillan.

Guignery, V. (2006). The fiction of Julian Barnes. London: Palgrave Macmillan

Hegarty, P. (2004). Jean Baudrillard: Live theory. London: Continuum.

Lane, R J. (2000). Jean Baudrillard. London: Routledge.

Rennison, N. (2005). Contemporary British novelists. London: Routledge. 